\title{
ŁUKASZ BERGER
}

Adam Mickiewicz University, Poznań

\section{THE OLD MAN AND LINGUISTIC POLITENESS IN THE COMEDIES OF PLAUTUS}

ABstract. Berger Łukasz, The Old Man and Linguistic Politeness in the Comedies of Plautus.

The aim of the article is to study the conversational behaviour of the Plautine old men in light of (im)politeness theory. The analysis concerns those scenes of salutatio and advice-giving where one of the speakers is a senex, in order to examine features of his linguistic characterisation.

Keywords: old men; politeness theory; Roman comedy; greetings; advising; persuasion.

Politeness, relatively recently introduced into linguistic theory, combines our communicative competences with the rules of social life by regulating the multidimensional interaction between individuals in a given cultural context. The efficient operation of closeness and distance allows us to achieve those conversational goals that are contrary to the addressee's expectations, since thanks to linguistic politeness we are able to effectively communicate our needs without compromising our social image. This image was called by E. Goffman 'face', which he more precisely defines as "the positive social value a person effectively claims for himself by the line others assume he has taken during a particular contact."1 The interlocutors' image constantly negotiated with their partners was successfully included in linguistic pragmatics by P. Brown and S. C. Levinson, ${ }^{2}$ authors of a much discussed, but still very influential, systematisation of the politeness phenomenon. ${ }^{3} \mathrm{~J}$. Hall remarks that the analysis tools that they

\footnotetext{
${ }^{1}$ Goffman 1955, 213.

${ }^{2}$ Brown, Levinson 1987. The main part of the book is a reprint of the authors' article published in 1978, in which they outlined their theory of politeness by referring not only to E. Goffman's concept of 'face', but also to H. P. Grice's conversational maxims.

${ }^{3}$ The sources and subsequent reception of the theory of P. Brown and S. C. Levinson are presented in a synthetic way by B. Pizziconi $(2009,706-710)$ (with further bibliography). The model of linguistic politeness developed by P. Brown and S. C. Levinson has been subject to justified criticism. More extensive empirical research in various languages and cultures have put into question the universality of certain polite linguistic behaviours. In addition, what has come to be questioned is the fixed link between politeness and its (often ossified) linguistic expressions, part of which are imposed by social
} 
developed prove to be useful for ancient texts, ${ }^{4}$ as long as the specific social relations of a given period and language system are taken into account.

Comedy dialogue seems to be a perfect corpus of texts to study the Roman concept of linguistic politeness, which has been shown by the interest this issue has recently aroused among scholars. ${ }^{5}$ The world of the palliata seems to reproduce artistically all the components of social reality. ${ }^{6}$ In most cases, the progression of events is achieved through the dialogue itself, during which strongly delineated interaction roles (e.g. adviser, advisee) are superimposed on the individual masks (senex, servus callidus, adulescens, etc.) of the characters. Each of them tries to pursue his own conversational goal, which often is contradictory to the wants of the other party. The cunning slave (servus callidus), for instance, in order to finance his young master's (adulescens) lavish entertainments and love affairs, will swindle money from his old master (senex), by cleverly manipulating his concern about the family reputation. Surely, the comedy stage is also ruled by farce, verbal abuse and aggressive humour, but no plan of Plautus' clever slave would work if he didn't first lure the victim into a web of intrigue composed, as I argue here, of verbal politeness. ${ }^{7}$

The victim of the deceit, the old father (senex), from the very beginning will seem to us - not without reason - the most polite person in the play. To some extent, the normative rules of polite expression must after all be associated with linguistic conventions and conservatism in speaking, which in the figure of the old man in the comedy perfectly fit in with his attachment to tradition and the

conventions with no relation to the users' strategic choice. Thus, later studies put more emphasis on the adherence of individual phenomena to the cultural specificity of a language community, and a more dynamic use of certain strategies during a given interaction. Perhaps the most extensive study in attempting to create a new model of politeness usable in empirical research is the study by R. J. Watts (2003), although even he failed to fully replace the classic tools developed by P. Brown and S. C. Levinson. Because of the specific features of the material selected here (the comedies by Plautus), we have also decided to keep to their more static methods of description, which do not require constant recourse to native speakers' intuition.

${ }^{4}$ Hall 2009, 7 (with further bibliography concerning the theory of politeness in the field of classical philology).

${ }^{5}$ Preliminary research in Roman comedy politeness was presented by R. Ferri (Ferri 2009), who restricted himself to several communication situations carried out by different characters of Plautus and Terence. The article of L. Unceta Gómez (2010, 625-637), focuses on a single illocutionary act and its context-bound linguistic expressions. My aim, in turn, is to examine politeness in relation to one type of interlocutor (both as the speaker and the addressee) - Plautus' old man.

${ }^{6} \mathrm{P}$. J. Burton $(2004,240)$, is convinced about the realism of the relations between Plautus' characters: "Plautus' infusion of the process on stage with all the raw emotional realism of daily life suggests that the playwright was trying to connect with his audience, to make his fellow Romans see something of themselves and their human relationships amidst the chaos and buffoonery of his staged situations."

${ }^{7}$ The pragmatic dimension of deceiving the Plautine master was tentatively explained in Berger 2013. 
established social order. ${ }^{8}$ Therefore, having a senex as the interlocutor is going to be an extremely important factor generating linguistic politeness. From applying Goffmanian theory to the palliata it follows that the old man in every (on-stage) interaction will have to (re)construct his 'face' as a respected paterfamilias, an educated Roman citizen (cf. Capt. 787: senex doctus) and influential statesman (cf. Cas. 536: senati columen, praesidium popli). Consolidating this interactive image largely depends on the other participants of the interaction, and is achieved through negotiation, ${ }^{9}$ in which politeness conventions (either used or rejected) will be the main tools to establish a common interpersonal ground. By using polite linguistic practices, the senex claims for himself his high social class (education level, wealthy status, etc.), whereas polite behaviour towards him proves that his interlocutor accepts the 'face' the senex is assuming. Accordingly, a hierarchy of power - either symmetrical (equal-to-equal) or asymmetrical (superior-inferior) - is being consolidated. ${ }^{10}$

Some conversational situations which may disturb the constant 'face' negotiations during the dialogue will become the critical moments in the process of constructing the interactive identity. According to the theory developed by P. Brown and S. C. Levinson, some speech acts may affect the interlocutors' images (the so-called 'face-threatening acts') and as such they require politeness strategies to mitigate their undesirable effect. ${ }^{11}$ In our case, any conversational actions implying that the old man is "out of the line", i.e. he is not deserving his high status, potentially poses a threat to his 'face'. Among all the acts of this type, this article will focus on the conversational situations that have become part of Plautus' theatrical conventions, and which constitute an important element of the plot pattern of most of the plays. I argue, therefore, that a key context for linguistic politeness is (1) the dialogue opening and (2) the major sequences of advice-giving.

In deciding to uptake the face-threatening acts, the interlocutors - according

${ }^{8} \mathrm{R}$. Maltby (1979) offers a study of old men's diction in Terence. Whereas the scholar is not concerned with strictly pragmatic phenomena, he argues that the use of archaisms and long-winded expressions, driven by linguistic conservatism, is a naturalistic feature of the Terentian senes.

${ }^{9}$ Goffman 1955, 213-214: "A person may be said to have, or be in, or maintain face when the line he [sic] effectively takes presents an image of him that is internally consistent, that is supported by judgements and evidence conveyed by other participants, and that is confirmed through impersonal agencies in the situation. [...] During a contact of a particular type, an interactant of known or visible attributes can expect to be sustained in a particular face and can feel that it is morally proper that this should be so."

${ }^{10}$ In such a meaning does J. Hall $(2009,12)$ compare E. Goffman's 'face' to the Roman dignitas of the senator class by rendering the conditions of single conversation into the broader context of public life: “An aristocrat's dignitas (like any individual's face) was not a stable, constant entity. It was always open to challenge and re-evaluation during the many (often public) encounters in which the aristocrat took part."

${ }^{11}$ Brown, Levinson 1987, 65-8. 
to the model of P. Brown and S. C. Levinson - may resort to two main politeness strategies. The first one (positive politeness) underlines a positive aspect of the recipient's 'face', that is, their drive for approval (affection, praise, inclusion within a group, etc.) on the part of the interlocutor, while the negative politeness type tends neither to limit the partner's freedom nor expose them to a loss of energy, time or means. ${ }^{12}$ Both aspects of good interpersonal relations with interlocutors are also taken into account by Cicero in the context of the Stoic ideals of social behaviour:

[...] sic eius modi motibus sermo debet vacare, ne aut ira exsistat aut cupiditas aliqua aut pigritia aut ignavia aut tale aliquid appareat, maximeque curandum est ut eos quibuscum sermonem conferemus et vereri et diligere videamur. (Cic. Off. 1, 136-emphasis mine.)

So, it seems that, according to the famous orator's suggestions, ${ }^{13}$ the two politeness strategies were also at work in ancient Rome: stressing the emotional bond with the addressees (diligere), and showing them distant respect (vereri). It should not be much of a misuse to combine the first attitude with indicating closeness to the interlocutor (positive politeness in the theory of P. Brown and S. C. Levinson), and equate the other type of strategy with respect not only for the addressee's status, but also his/her freedom of action (negative politeness). ${ }^{14}$

The main focus in the further part of the paper will be to determine which politeness strategies are preferred by Plautus' old men and their interlocutors. Also, it will prove valuable to indicate some failed attempts to save/maintain the partner's 'face' as well as to highlight the cases of utter unwillingness to employ any redressive or mitigating action (i.e. linguistic impoliteness).

\section{DIALOGUE OPENING}

The initial phase of the conversation is one of the most ritualised parts of the global conversational structure. The dialogue opening is a critical moment with repercussions for the whole interaction, since it poses a serious threat to the 'face' of the contact initiator: s/he may find the addressee reluctant to talk or temporarily unavailable, and thereby the initiator may seem to be a nuisance or

${ }^{12}$ Brown, Levinson 1987, 70.

${ }^{13} \mathrm{~A}$ similar combination in the context of relations between friends: neque solum colent inter se et diligent, sed etaim verebuntur (Cic. Amic. 82) - both examples discussed by J. Hall (2009, 8-9).

${ }^{14}$ Hall $(2009,8-15)$, beside the traditional notions of P. Brown and S. C. Levinson's positive politeness (affiliative in his terminology) and negative politeness (redressive), also distinguishes a third type - the politeness of respect, which he closely relates to social status and Roman dignitas. As such formal relations, typical of political life, hardly occur in the palliata, highlighting the difference between negative aspects of politeness and respect seems here to be superfluous. 
be rejected outright. The other party, in turn, may feel him/herself compromised to engage in an unwanted conversation to avoid the impression of being "hardto-reach." ${ }^{15}$ In this context, J. Laver stresses the interdependence of the high level of linguistic formularity and the politeness phenomenon: "maximum risk leads to [the] maximum routine", and respectively "maximum routine reflects [the] highest risk." 16

Whereas most of the salutatio scenes are dominated by the affiliative aspect of polite behaviour, the relationship between Demipho and Lysimachus (Merc. 283-90) is marked by a much greater role of negative politeness, as the matter with which the former comes to his neighbour is rather delicate.

DEM. Lysimache, salve.

LYS. Eugae, Demipho, / salveto. quid agis? quid fit?

DEM. Quod miserrumus. /

LYS. Di melius faxint!

DEM. Di hoc quidem faciunt.

LYS. Quid est? /

DEM. Dicam, si videam tibi esse operam aut otium. /

LYS. Quamquam negotium est, si quid vis, Demipho, / non sum occupatus umquam amico operam dare. /

DEM. Benignitatem tuam mi experto praedicas. / quid tibi ego aetatis videor? (Merc. 283-90) ${ }^{17}$

The beginning of the contact between the old men seals the friendly relationships between them: the nominal address forms (Lysimache, Demipho) and common greeting formulae (salve, salveto) testify to a closeness between the interlocutors. Despite an apparent reciprocity in their relations, it's Lysimachus who reacts enthusiastically at the sight of his neighbour (eugae $\left.{ }^{18}\right)$, and suggests introducing a preliminary recipient-oriented subject of the conversation (quid agis?) followed by a more general quid fit?, while Demipho intentionally omits this part of the conversation to pass more quickly ad rem. As a matter of fact, he starts a conversation with his friend to confide his feeling towards a young

${ }^{15}$ Cf. Mil. 1224-6: ACRO. Permirum ecastor praedicas, te adiisse atque exorasse; / per epistulam aut per nuntium, quasi regem, adiri eum aiunt. / MILPH. Namque edepol vix fuit copia adeundi atque impetrandi.

${ }^{16}$ J. Laver 1981, 290.

${ }^{17}$ The Plautine text, here and below, is cited according to the latest edition by W. De Melo, Plautus. Comedies. I-V, Cambridge 2011-2013.

${ }^{18}$ The exclamation of eug (a)e is analysed by L. Unceta Gómez (2012, 376-378). In Roman comedy, as the scholar argues, it is a feature of emotional and colloquial language. Among other uses, the exclamation $\operatorname{eug}($ a)e occurs as a spontaneous reply to a friendly greeting - most often uttered by a young man (Merc. 601, Most. 399) or a slave (Pseud. 712, Rud. 415, Stich. 660, Ter. And. 344-5). It's worth noting that sometimes it is also used by old men (Bacch. 1105, Most. 1076) who want to express their joy at meeting another (well-known) character. See also Ferri (2009, 19), who mentions its Greek origin (gr. $\varepsilon \tilde{u}$ ), while pointing out that the context of its use in the palliata differs from the interactive meaning in Menander. 
courtesan, although he realises that such a confession can end up in losing his 'face'. ${ }^{19}$ Hesitating to enter into a new role, ascribed in the Roman comedy to the always ridiculed senex amator (an old husband in love with a young prostitute), he is reluctant to give a direct answer about his problems. Instead he leaves a series of general hints - by evoking empathy (quod miserrumus) or curiosity (di hoc quidem faciunt) - in order to give Lysimachus a chance to 'unpack' his troubles on his own. Thus, Demipho delays the main subject of the conversation, demanding from the other party tokens of emotional engagement. As a part of the same strategy, he tries to convince his interlocutor that he doesn't want to unnecessarily take up his time or bore him with his matters (dicam, si videam tibi esse operam aut otium), underlining the respect he has for him (and his resources), that is to say, towards his negative 'face'. This consequent use of negative politeness inclines Lysimachus to emphatically declare his readiness to hear out his friend (287-288), and allow Demipho's next move. The troubled senex, before he finally passes on to the embarrassing confession, responds also to the positive face-wants of his interlocutor by evoking his companion's kindness (289: benignitatem tuam mi experto praedicas). In such a way, the old man's politeness, dominated by withdrawal, is to compensate for the face-threat, posed by the confession that he is no longer a senati columen nor praesidium popli (Cas. 536) but rather a senex amator, ${ }^{20}$ prone to be mocked.

The conventions of polite greeting scenes between old men are so strong that even a companion's reprimand must be preceded by a social ritual. In the following excerpt, Megaronides, who suspects that Callicles has abused the trust of his neighbour Charmides, is resolute to overtly criticise his vile behaviour (Trin. 25-6: MEG. [...] ego amicum hodie meum / concastigabo pro commerita noxia).

CAL. Quoia hic vox prope me sonat? /

MEG. Tui benevolentis, si ita es ut ego te volo, / sin aliter es, inimici atque irati tibi. /

CAL. O amice, salve, atque aequalis. ut vales, / Megaronides?

MEG. Et tu edepol salve, Callicles. /

${ }^{19}$ Demipho's fear of losing his 'face' is even articulated expressis verbis, when the old man demands to be assured that his friend's perception of him has not changed (Merc. 322-3: DEM. At ne deteriorem tamen / hoc facto ducas. LYS. Egon te? ah, ne di siverint.).

${ }^{20} \mathrm{In}$ fact, the moment of proper confession is delayed even more. First, Demipho asks his friend how old he looks (Merc. 290), and where everything seems to indicate that the chat between both old men concerns their state of health (297-8), the loving man will resume preparing the ground for a face-threatening confession (301: DEM. Sed ausimne ego tibi eloqui fideliter?). When finally Demipho confesses his feelings (304), he is ridiculed by his interlocutor, despite his endeavours to save his 'face'. The old man's suspense-building courtesy thereby seems to intensify the comic effect of the entire scene of ridiculing the senex amator (313-5). The success of the politeness strategy, however, can be confirmed by the dialogue ending, where both characters say goodbye in a friendly manner to acknowledge that their relations have not been damaged (327: DEM. Bene ambulato. LYS. Bene vale. DEM. Bene sit tibi). 
CAL. Valen? valuistin?

MEG. Valeo, et valui rectius. (Trin. 45-50)

Although the old man's first words anticipate his ambivalent feelings towards the interlocutor (46-7: tui benevolentis [scil. vox], si ita es ut ego te volo), the principle of reciprocity in non-hostile contacts with a friend makes him preserve all the forms of conventional dialogue opening. Since Callicles welcomes his friend with a full sequence of nominal address, a salutation formula and a 'how-are-you' question (48-9: CAL. O amice, salve, atque aequalis. ut vales / Megaronides?), Megaronides responds accordingly with a short greeting (et tu ... salve) and a nominal address. He even engages in a longer 'small talk' concerning his wife's health, and mentions several (typical for the genre) ironic remarks on marriage relationships (51-65), which despite the comic effect bears fruit also in building male solidarity between the interlocutors.

MEG. [...] sed hoc animum advorte atque aufer ridicularia; / nam ego dedita opera huc ad te [ad]venio.

CAL. Quid venis? /

MEG. Malis te ut verbis multis multum obiurigem. (Trin. 66-8)

The whole ritual on the part of Megaronides is a kind of repayment of a courtesy debt that is to compensate for the following (face-threatening) act of accusing the Callicles ${ }^{21}$ of breaching their mutual friend's trust. Before the accuser gets to the point, however, he will signal a sudden change of subject and tone of their meeting (66-7). This time, the affiliative aspects of politeness concerned in building closeness precede a bitter pill of criticism (68), making it, somehow, easier to swallow. ${ }^{22}$

When Charmides, who also wrongly suspects Callicles of treason, returns to town, his behaviour will no longer be so well-balanced. Instead of greeting his friend after a long absence, he calls him out (up to three times!) with a ceremonial mock-tragic $O$ Callicles! (1094), followed - instead of a greeting formula - by an accusation in the form of a rhetorical question (1095).

${ }^{21}$ Criticising a friend as a face-threatening act in social reality depicted by the palliata is testified, among others, by Sosia's cynical words: sapienter vitam instituit; namque hoc tempore / obsequium amicos, veritas odium parit. (Ter. And. 67-8).

${ }^{22} \mathrm{P}$. J. Burton, (Burton 2004, 226), looks into this scene in order to study amicitia as a processual phenomenon. He comes to the conclusion that Megadorus' criticism did not destroy his close relations with Callicles, because it sprang from loyalty towards their mutual friend: "Plautus thus externalizes and articulates here a complicated process whereby Callicles' friendly act of fides on behalf of Charmides serves to defuse a potentially difficult test of the fides between Callicles and Megaronides." It seems that his analysis of the relations between the characters can also be supplemented with our politeness-strategy arguments for the salutatio scene and the long 'small talk' sequence - passages that this scholar omits in his reasoning. 
CAL. Quid hoc hic clamoris audio ante aedis meas? /

CHAR. O Callicles, o Callicles, o Callicles! / qualine amico mea commendavi bona? /

CAL. Probo et fideli et fido et cum magna fide. / et salve et salvom te advenisse gaudeo. (Trin. 1093-7)

Convinced of his innocence, Callicles tries to defend himself (1096), although he does not forget about the due linguistic ritual of welcoming the traveller (1097: et salve et salvom te advenisse gaudeo). ${ }^{23}$ In the dialogue opening he gives Charmides back what he himself has not received, as if he implicitly rebukes his interlocutor's lack of manners. Callicles' knowledge of linguistic courtesy conventions seems to fulfil the same function in his utterance as the emphatic evoking of fides $^{24}$ - it reaffirms his image of a respected Roman citizen, well aware of the mechanisms of social life. As such, he would not be capable of treason, which he finally proves to Charmides further on in the play (1125-7).

Whereas in the discussed scene the omission of greeting by the old man could be interpreted by his interlocutor as a sign of impoliteness, the subsequent fragment will show that excessive politeness in salutatio may also get a negative assessment.

MEG. Salvos atque fortunatus, Euclio, semper sies. /

EUC. Di te ament, Megadore.

MEG. Quid tu? recten atque ut vis vales? (Aul. 182-3)

A Plautine miser, Euclio, is very effusively greeted by his neighbour ( $A u l$. 182: salvos atque fortunatus, Euclio, semper sies). ${ }^{25}$ Then, he is asked, rather insistently, about his state of health (183: quid tu? recten atque ut vis vales?). Such a dose of positive politeness arouses in Euclio a serious suspicion about his interlocutor's sincere intentions (185: EUC. [...] iam illic homo aurum scit me habere, eo me salutat blandius). Obsessed with a treasure hidden in the house, the old miser wrongly interprets Megadorus' acts of kindness: an expression of empathy as a reaction to Euclio's complaints on his alleged poverty (187: MEG. Pol si est animus aequos tibi, sat habes qui bene vitam colas), or even an offer to help (193: dabitur, adiuvabere a me. dic, si quid opust, impera).

${ }^{23}$ The formula salvom te venire gaudeo (and its variants) normally appears as a secondary greeting expression in the home-coming scenes, i.e. in welcoming characters returning from journeys abroad (e.g. Epid. 128; Stich. 584-5; Trin. 1073, 1097).

${ }^{24}$ For more on fides in the friendly relations of Plautus' characters, see Burton 2004, 219 28. His detailed research shows that this is a highly appreciated value in close contacts between Roman citizens, an example of which is the fact that disappointed confidence (perfidia) can turn friends into deadly enemies in the blink of an eye.

${ }^{25}$ The greeting by Megaronides employs a common formula salvos, - a sis (e.g. Bacch. 536, Men. 775, Mil. 902, Truc. 358), but here it is considerably extended. 
MEG. Da mi operam parumper; paucis, Euclio, est quod te volo / de communi re appellare mea et tua.

EUC. Ei misero mihi, / aurum mi intus harpagatum est. nunc hic eam rem volt, scio, / mecum adire ad pactionem. verum intervisam domum. /

MEG. Quo abis?

EUC. Iam revortar ad te: nunc est quod invisam domum. (Aul. 199-203)

When finally Euclio's interlocutor considers the welcome ritual has been completed, and decides to get to the point by signalling viva voce this conversational action in accordance with the conventions of a symmetrical (i.e. equal-to-equal) conversation (199-200), his interlocutor suddenly breaks the contact, and leaves without saying 'goodbye' (203). Even such an overdrawn example of failed interaction suggests that, while exceptionally complex opening sequences in comedy conventionally pertain to old men, the politeness phenomena are always subject to the interpretation of the interlocutors. Excess of courtesy in the greeting scene (blandius salutare) in this case produces an effect opposed to the intended one, and instead of building friendly relations between the characters, it provokes mistrust. ${ }^{26}$

To complete the picture of polite behaviour typical of the senex in a dialogue opening, it is worth offering some more examples, in which the old men encounter other types of character. Both youths and slaves usually recognise the high social status of the senes, which is confirmed in the greeting scenes. When the old Theopropides returns unexpectedly from his journey (Most. 447-9), his son's servant welcomes him in an (apparently) enthusiastic and ceremonial manner, one that does not vary from the formulae used by free citizens (cf. Trin. 1093-7 above): after an official nominal address ( $O$ Theopropides), there follows another vocative (ere) emphasising the slave's subjection to the recipient, a customary - given the circumstances - greeting formula (salvom te advenisse gaudeo) and a question about health (usquin valuisti?) that follows the 'small talk' scheme.

THEO. Meus servos hicquidem est Tranio.

TRA. O Theopropides, /ere, salve, salvom te advenisse gaudeo. / usquin valuisti?

THEO. Usque ut vides.

TRA. Factum optime. /

THEO. Quid vos? insanine estis?

TRA. Quidum? (Most. 447-50)

The only perceivable difference in the contact with a low-status character is the old man's perfunctory reply (449: usque ut vides) or even total lack of

\footnotetext{
${ }^{26}$ Euclio's mistrust towards Megadorus is not an isolated case. His other acquaintances' conversational behaviour seems to him equally suspicious (cf. Aul. 114-5: EUC. [...] omnes videntur scire et me benignius / omnes salutant quam salutabant prius).
} 
reciprocity in the individual conversational moves. A completely different attitude is presented by Theopropides during his meeting with his son's friend, the young free citizen Callidamates.

CAL. [...] iubeo te salvere et salvos cum advenis, Theopropides, / peregre, gaudeo. hic apud nos hodie cenes, sic face. /

THEO. Callidamates, di te ament. de cena facio gratiam. (Most. 1128-30)

The youth seems to "pay" a greater dose of positive politeness by officially greeting the old man with a complex sequence of salutation forms (1128-9: iubeo te salvere et cum advenis, Theopropides, / peregre, gaudeo) and by inviting the new-comer to a feast (hic apud nos hodie cenes, sic face). Still, Theopropides responds to his every move separately (1130). He greets him formally with a blessing formula (di te ament), and indirectly refuses to come for the banquet (de cen a facio gratiam). Thereby, the old man pays most of the politeness debt he owes to the boy, but, at the same time, he does not fall out of his higher interactive role of the venerable senex.

As for the slave, we must emphasise the ambivalent position taken in the comedy by the servus callidus, who on the stage frees himself from any norms of social behaviour, those of linguistic politeness included. ${ }^{27}$ His approach to the conversational conventions is therefore very goal-oriented. Before he carries out his plan, the slave emphasises his closeness to the old master in order to win his trust (cf. above Most. 447-9), but when he wants to play the role of an obedient servant, he immediately resorts to the negative politeness strategy.

TRA. Siquidem pol me quaeris, assum praesens praesenti tibi. /

THEO. Eugae! Tranio, quid agitur? (Most. 1075-6)

In such a way does Tranio (1075-6) try to convince his master that he is always at his disposal, keeping a proper (interpersonal) distance and showing due respect. ${ }^{28}$

If one keeps in mind the characterization of the Plautine senes presented above, any verbal aggression towards the old man from low-status characters will seem all the more inappropriate. The aforementioned Theopropides (Most. 939-42), in seeing young slaves banging on his door, feels fully entitled to call

${ }^{27}$ This rule is confirmed by R. Ferri $(2009,24)$ based on examples not only from welcome scenes: "[...] when a slave adopts elaborate politeness strategies, it is either because he is enacting a role (for example he is dressing as a stranger of free birth) or he is trying to set up a subterfuge of some sort."

${ }^{28}$ Cf. Amph. 956: SOS. Amphitruo, assum. si quid opus est, impera, imperium exsequar. Similarly behaves the young man who has recently shed his slave's attire in Capt. 978: PHILOCR. Hegio, assum. si quid me vis, impera. 
them using the emotional authoritarian appellative heus vos $!^{29} \mathrm{He}$ does not expect, however, that the unknown pueri, totally unaware that they are talking to this household's pater familias, will respond to him in the very same way, disregarding his social status (940: heus senex) and omitting any politeness tokens.

THEO. Heus vos, pueri, quid istic agitis? quid istas aedis frangitis? /

PHAN. Heus senex, quid tu percontare ad te quod nihil attinet? /

THEO. Nihil ad me attinet?

PHAN. Nisi forte factu's praefectus novos, / qui res alienas procures, quaeras, videas, audias.

(Most. 939-42)

The old man's indignation at the overt attack on his 'face' can be acknowledged, among others, in the indignation he expresses by repeating their rough teasing (941: THEO. Nihil ad me attinet?; cf. 955: THEO. Tu ne molestu's).

The on-stage impoliteness towards the old man is striking especially in view of the fact that he sometimes becomes the censor of others' inappropriate conversational behaviour. In a dialogue opening with a familiar-looking woman of Epidauros, Periphanes (Epid. 549-9) launches a greeting (salva sis). Almost immediately, however, he is forced to intervene when his female interlocutor responds to his speech act in an infelicitous way (salutem accipio mi et meis), by failing to reciprocate the courtesy.

PER. Salva sis.

PHIL. Salutem accipio mi et meis.

PER. Quid ceterum?/

PHIL. Salvos sis: quod credidisti reddo.

PER. Haud accuso fidem. (Epid. 548-9)

A kind of meta-pragmatic admonition quid ceterum? is a sign for the woman that her repayment of the politeness debt has not been sufficient. Only the exact repetition of Periphanes' formula (salvos sis) restores the interactional balance and fulfils the greeting ritual (quod credidisti reddo). In this way does the senex not only construct his interactive identity as a Roman citizen with a high pragmatic competence but also indicates his communicative superiority over a female character.

\section{ADVISING}

In Plautus' comedies, the old man's political influence is often emphasised (Epid. 522-3: omnium / legum atque iurum fictor, conditor). As a respected

\footnotetext{
${ }^{29} \mathrm{Cf}$. Berger 2015.
} 
Roman citizen, he takes part in the work of the Senate, ${ }^{30}$ which he doesn't fail to mention on the stage (Mil. 592), and which wins favour with his wife (Cas. 536), besides general social esteem (Capt. 787: hic illest senex doctus, Merc. 319: vir spectatus). A significant threat to the image of such a public figure would be to give him advice, especially in matters concerning his own family. According to J. R. Searle, the adviser by advising some future act A must have some reason to believe the hearer (the advisee) will benefit from doing $\mathrm{A}$, whereas it is not obvious for both the adviser and the advisee that the latter would do A in the normal course of events. As the linguist points out: "Advising you is not trying to get you to do something in the sense that requesting is. Advising is more like telling you what is best for you." 31

Having that in mind, we have considered this face-threatening act as an important context for linguistic politeness in Roman comedy. Firstly, in interactions among equals (like senes) counselling and advising may lead to a disturbance of the balance of power between the parties, as any adviser, whether they want it or not, patronises the person they advise (the advisee). Communicative caution is also required in the way one reacts to the interlocutor's advice: rejecting their remarks may imply the failure to see their good intentions or the validity of their point of view, while excessive enthusiasm in accepting advice suggests the recipient's total submission, contrary to their high social position. Various politeness strategies help overcome this conversational impasse.

In one scene, Simo complains out loud about his typical family problem: there are rumours in town about his son's feelings towards a certain prostitute for whom he will probably try to wangle his father's money (Pseud. 415-22). Simo's friend, old Callipho, in order to calm him down, presents his balanced point of view (427-9). As nobody asked him for advice, however, he starts with a very general statement that he approves neither of those who spread rumours (qui gestant crimina), nor those who listen to them (qui auscultant). Obviously, the latter (auditores) include Simo as well, so in saying that people sensitive to rumours deserve being hanged by their ears (429) is actually a very daring criticism of the interlocutor.

CALL. Homines qui gestant quique auscultant crimina, / si meo arbitratu liceat, omnes pendeant, / gestores linguis, auditores auribus. / nam istaec quae tibi renuntiantur, filium / te velle amantem argento circumducere, / fors fuat an istaec dicta sint mendacia; / sed si sint ea vera, ut nunc mos est, maxume, / quid mirum fecit? quid novom, adulescens homo / si amat, si amicam liberat?

PSEU. Lepidum senem. /

SIMO. Vetus nolo faciat.

${ }^{30}$ When in a comedy upside-down world social roles get reversed, the witty slave will be holding a symbolic Senate session in his head using all his intellectual talents (Epid. 159; Most. 688, 1049).

${ }^{31}$ Searle 1969, 67. 
CALL. At enim nequiquam nevis; / vel tu ne faceres tale in adulescentia. / probum patrem esse oportet qui gnatum suom / esse probiorem quam ipsus fuerit postulet. / nam tu quod damni et quod fecisti flagiti / populo viritim potuit dispertirier. / idn' tu mirare, si patrissat filius? (Pseud. 427-42)

To compensate for the attack on the recipient's 'face', Callipho resorts to negative politeness, not only avoiding a direct confrontation with Simo, but also making sure whether it's right to speak up in this matter (si meo arbitratu liceat). The old man's words hide some implicit advice for his companion to downplay his son's flirtation, all the more so as such behaviour is nothing new or surprising these days (433-5).

Because of Simo's reluctance to see in this way the whole matter, Callipho decides to reach for another - this time positive - strategy: bringing back their mutual close relationship. First, however, he does not hesitate to overtly ignore his interlocutor's protest (436: at enim nequiquam nevis) or indicate an analogy between the reckless behaviour of the amorous son, and a similar history from his father's youth (436-42). The strength of Callipho's arguments is not only limited to proving hypocrisy in his interlocutor's attitude, but takes the opportunity to evoke the old men's long acquaintance. ${ }^{32}$ Where the adviser abandons a sententious tone (438-9) in favour of a more direct approach to the recipient (cf. emphatic use of pronoun $t u-437,440,442$ ), correcting Simo's actions seems to be justified by their friendly relations.

Unfortunately, we do not know the old man's reaction to such a rhetoric devised by his companion, because their conversation is suddenly interrupted by the slave Pseudolus, the young man's accomplice (446: hic dux, hic illi est paedagogus), who was eavesdropping in secret. Now, Simo's anger is focussed on his witty servant, whom he wants to punish forthwith.

SIMO. Quis hic loquitur? meus est hic quidem servos Pseudolus. / hic mihi corrumpit filium, scelerum caput; / hic dux, hic illi est paedagogus, hunc ego / cupio excruciari.

CALL. Iam istaec insipientia est, / iram in promptu gerere. quanto satius est / adire blandis verbis atque exquaerere, / sintne illa necne sint quae tibi renuntiant. / bonus animus in mala re dimidium est mali. /

SIMO. Tibi auscultabo. (Pseud. 445-53)

A voice of reason, nonetheless, comes back in Callipho, and he tries to dissuade his friend from such a hasty reaction. Once again, he significantly disguises his advice as a series of gnomic recommendations (448-9: Iam istaec insipientia est, / iram in promptu gerere; 452: Bonus animus in mala re dimidium

${ }^{32}$ Knowing the fiction conventions of the palliata, we can assume that Callipho, as Simo's friend some years ago, played the role of amicus sodalis, offering him advice and material assistance in his troublesome love affair. So, now he seems even more entitled to advise his old companion, while siding with the enamoured son, and not the father. 
est mali). Such a (negative) strategy protecting the image of the interlocutor, who is being admonished, achieves the desired effect. Simo succumbs to his friend's suggestion with no major reservations (453: SIM. Tibi auscultabo), restraints his anger, and engages in conversation with the slave, which will get him involved in Pseudolus' intrigues. This, in turn, will result in making all the initial fears of the old man a reality. ${ }^{33}$

A different type of relationship between both senes will be set up in the scene of advice being given upon the clear request of one of them. ${ }^{34}$ After a test of friendly loyalty between Callicles and Megaronides (cf. above Trin. 45-68), both men meet again to decide together if it is better to marry off their common friend's daughter without a dowry, or tell her and her brother about the hidden family treasure. The neighbour's intervention is also a reaction to Callicles' previous request, and a fulfilment of his friendly promise (Trin. 189-91).

Even in such circumstances do both old men feel obliged to follow certain politeness guidelines not to destroy the balance of power. Every proposition of Megaronides, acting here as adviser, takes advantage of the negative politeness strategy, thus presupposing the recipient's discretion, and avoids too self-imposing suggestions (734: nisi expectare vis, 744: nunc si opperiri vis adventum Charmidi). Naturally, the speaker has greater reservations toward some solutions, but he prefers to present them as his own concerns (738: verum hoc ego vereor) than categorically reject them as incorrect ways of overcoming the problem. We assume he does so in case his interlocutor has quite different views.

MEG. Parata dos domi est; nisi expectare vis, / ut eam sine dote frater nuptum collocet. / post adeas tute Philtonem et dotem dare / te ei dicas, facere id eius ob amicitiam patris. / verum hoc ego vereor, ne istaec pollicitatio / te in crimen populo ponat atque infamiam; / non temere dicant te benignum virgini: / datam tibi dotem, ei quam dares, eius a patre, / ex ea largiri te illi, neque ita ut sit data / columem te sistere illi, et detraxe autument. / nunc si opperiri vis adventum Charmidi, / perlongum est: huic ducendi interea apscesserit / lubido; atque ea condicio huic vel primaria est. /

CAL. Nam hercle omnia istaec veniunt in mentem mihi. / vide si hoc utibile magis atque

${ }^{33}$ The role of Callipho in the scene of launching the intrigue is much more important than it might appear. Paradoxically, the old man's friend seems to support Pseudolus (Pseud. 519, 523), and eagerly becomes the first spectator in the show of his wit (551-4) announced to Simo. The slave also speaks very flatteringly of his master's companion (435: lepidum senem, cf. 443-4), and in the crucial moment for the development of the further plot, both characters even seem to cooperate. Taking advantage of his close relations with Simo, Callipho advises him to participate in a wager with the deceitful servant (537-8: CAL. Ius bonum orat Pseudolus; / dabo inque), which he finally does (446). From the beginning of the scene, all the actions of the old friend and pieces of advice given to Simo seem simply to support Pseudolus' scheme, and allow him to carry out his daring fraud.

${ }^{34}$ In general, the pieces of advice and opinions given on the interlocutor's request seem to be less threatening (cf. Pseud. 476: SIM. [...] quid censes? CAL. Edepol merito esse iratum arbitror). 
in rem deputas, / ut adeam Lesbonicum, edoceam ut res se habet. / sed ut ego nunc adulescenti thesaurum indicem / indomito, pleno amoris ac lasciviae? (Trin. 734-51)

Megaronides' line of reasoning and farsightedness are clearly appreciated in his interlocutor's utterance. It is an opportunity for Callicles to emphasise that he shares the same objections with his partner (747: Nam hercle omnia istaec veniunt in mentem mihi), and the balance between the adviser and the advisee still has not been disturbed. The interactional roles are not yet clearly ascribed. As if to confirm this state of affairs, old Callicles sketches on his own a possible solution of the problem by preceding it with a deferential comment in which he indicates that he considers this matter as yet to be decided, and only asks his friend for his opinion (748: vide si hoc utibile magis atque in rem deputas). Before he completes his utterance, however, he realises that his proposition will also produce no effect (752: minime, minime hercle vero).

So, the debate is pending, although the initiative seems to be taken again by Megaronides, who brings himself to very abruptly reject (760: gerrae $!^{35}$ ) his interlocutor's idea of borrowing money from a friend. Finally, the old man hits upon a final plan for solving the entire matter - a typically Plautine masquerade that will allow him to provide the dowry for Charmides' daughter without the need to inform his children of the treasure. For politeness reasons, however, he postpones the moment of revealing the entire project to Callicles, and emphasises that it is only an option (763: Sed vide consilium, si placet). As a matter of fact, Megaronides seems already convinced about the superiority of his own idea over the other mentioned solutions, but prefers to stress the subjectivity of his evaluation (764: Scitum, ut ego opinor, consilium inveni), and intrigue Callicles so as to make him himself demand the plan to be revealed (763: CALL. Quid consilist?; 764: CALL. Quid est?). In this way, Megaronides finally consolidates his role of the one being advised by just limiting himself to impatiently asking for the individual stages of putting the intrigue into practice $(766,777)$ or express appreciative praises $(780,783,786)$.

MEG. Sed vide consilium, si placet.

CAL. Quid consili est? /

MEG. Scitum, ut ego opinor, consilium inveni.

CAL. Quid est? /

MEG. Homo conducatur aliquis iam, quantum potest, / quasi sit peregrinus.

CAL. Quid is scit facere postea?

${ }^{35}$ The exclamation gerrae ("nonsense!") appears several times in Plautus' comedies (and none in Terence), although most often within one character's utterance as a summary of a certain state of affairs (Asin. 600, Epid. 233). One time it refers directly to the interlocutor's behaviour (Poen. 137), but then it is introduced as an expression of a strange tone, one that requires a special gloss (quod dici solet). 
MEG. Is homo exornetur graphice in peregrinum modum. / ignota facies quae $<$ hic $>$ non usitata sit; / mendaciloquom aliquem-

CAL. Quid is scit facere postea? /

MEG. - falsidicum, confidentem -

CAL. Quid tum postea? (Trin. 763-70)

The old man's submission in accepting advice reassures, only more strongly, Megaronides in his having the dominant position of the interactant who dictates recommendations. Having abandoned the negative politeness strategies, the adviser rejects with slight contempt his interlocutor's reservations concerning his brilliant plan (790: Etiam tu taces?), and mentions "hundreds" (sescentae) of possible solutions to potential complications (791-7). He does not even wait for Callicles' final consent and approval of the project, but immediately takes on the role of the intrigue's architect, and like a comedy servus callidus gives his interlocutor a series of detailed orders (798-805) complaining about inactive waste of time (802: quid nunc stas? quin tu hinc amoves et te moves?, cf. 806, 811).

\section{CAL. Scite hercle sane!}

MEG. Hoc, ubi thesaurum effoderis, / suspicionem ab adulescente amoveris: / censebit aurum esse a patre allatum tibi, / tu de thesauro sumes.

CAL. Satis scite et probe; / quamquam hoc me aetatis sycophantari pudet. / sed epistulas quando opsignatas adferet, / nonne arbitraris eum adulescentem anuli / paterni signum nosse?

MEG. Etiam tu taces? / sescentae ad eam rem causae possunt colligi [...] / abi ad thesaurum iam confestim clanculum, / servos ancillas amove. atque audin?

CAL. Quid est? /

MEG. Vxorem quoque eampse hanc rem uti celes face, / nam pol tacere numquam quicquamst quod queat. / quid nunc stas? quin tu hinc amoves et te moves? / aperi, deprome inde auri ad hanc rem quod sat est, / continuo operito denuo; sed clanculum, / sicut praecepi; cunctos exturba aedibus. /

CAL. Ita faciam. (Trin. 783-806)

What has imperceptibly changed is the initial situation, when two senes would talk to each other jointly concocting a plan of action, and considering the advantages and disadvantages of individual ideas. As soon as the interaction roles of the adviser and the advised could be more clearly discerned, each interlocutor resorts to different politeness strategies to preserve but an apparent balance between each other. In the end, however, as we have just seen, the conversation was dominated by Megaronides, who suddenly ceased bothering about mitigation and redressive action towards his interlocutor. His only objective (also from the perspective of the plot) was to efficiently design the intrigue (cf. 819: MEG. Actum reddam nugacissume).

When at the beginning of Epid. (166-90) two old men appear on the stage, we can already hear the main topic of their dialogue. Apoecides tries to convince his companion that there is nothing wrong in marrying a poor woman. He also uses 
strategies of presenting pieces of advice as very general moral recommendations (166-8: plerique homines...), and only later refers them directly to the recipient (169: ... is adeo tu es). This apparent caution used by Apoecides in attempting to influence his friend is soon replaced by reducing the distance between them in telling a bitter joke about the late wife of his interlocutor (173-7). The favourable reaction of the widower Periphanes shows that this move was received as a positive (affiliative) politeness strategy, and both men engage in some brief sympathising 'small talk' concerning the hardships of marital life (177-80). The further part of the conversation concerns Periphanes' son. In view of the only just consolidated closeness between the old men, Apoecides does not hesitate to advise something without compensating for this face-threatening act (189-90), which meets with the interlocutor's full approval (PER. Laudo consilium tuom).

The scene is interrupted by the appearance of the slave Epidicus, who, seeing an opportunity for himself in this situation, meddles in the conversation carried on by the senes. What happens further on provides valuable information concerning the construction of advising discourse with the participation of old men and lower status characters. First, the witty slave gets Periphanes cross with off-hand made-up rumours by informing him that his son has become a laughing stock of the whole city because he is chasing after a certain female lutenist.

PER. Quid ego faciam? nunc consilium a te expetesso, Apoecides. /

AP. Reperiamus aliquid calidi, conducibilis consili. / nam illequidem aut iam hic aderit, credo hercle, aut iam adest.

EPI. Si aequom siet / me plus sapere quam vos, dederim vobis consilium catum, / quod laudetis, ut ego opino, uterque-

PER. Ergo ubi id est, Epidice? /

EPI. -atque ad eam rem conducibile.

AP. Quid istuc dubitas dicere? /

EPI. Vos priores esse oportet, nos posterius dicere, / qui plus sapitis.

PER. Heia vero! age dic.

EPI. At deridebitis. /

AP. Non edepol faciemus.

EPI. Immo, si placebit, utitor, / consilium si non placebit, reperitote rectius. / mihi istic nec seritur nec metitur, nisi ea quae tu vis volo. /

PER. Gratiam habeo; fac participes nos tuae sapientiae. (Epid. 255-66)

Obviously, the old father hurries to ask for advice from his old friend (255: PER. [...] consilium a te expetesso, Apoecides), whose only recommendation (on an $a d$-hoc basis) is to act quickly before the young man comes back home (256-7). This apparent powerlessness of Periphanes' trustee is immediately taken advantage of by the cunning Epidicus who is waiting for a suitable moment to win both characters over to his (already designed) plan. Before he dares to advise anything to the respected and venerable Roman citizens, however, the "humble" servant reaches for the negative politeness strategy by underlining his low position in the hierarchy. First, Epidicus, quite hypocritically, questions the 
significance of his intellect (257-8: Si aequom siet / me plus sapere quam vos), and emphasises subjectivity of the evaluation of his proposition (ut ego opino). Confident that neither of the old men will come up with a better solution, he calls on them to speak up first (261: Vos priores esse oportet, nos posterius dicere).

His interlocutors' helplessness and impatience are most manifested in the way they take turns to encourage him to reveal his idea $(260,262)$ even by interrupting Epidicus' captatio benevolentiae full of (fake!) respect (259). Epidicus' last utterance before enunciating the plan is a skilful combination of distance (264: si placebit; 265: si non placebit) and closeness politeness (266: ea quae tu vis volo). Periphanes, conquered by such a respectful attitude of the slave, feels obliged to sincerely thank him for the favour. The old man seems not to realise that thereby he consents to a new division of the interactional roles (266: fac participes nos tuae sapientiae). The Plautine senes have just agreed to participate in a new power hierarchy: in strong dependence on the slave-adviser.

Epidicus is still cautious, being aware that excessive arrogance in advising the senes will not gain their respect - on the contrary - it may lead his plan to a failure. Therefore, he begins with repeating the first advice of Apoecides (18990: AP. Continuo ut maritus fiat) concerning early marriage (267: EPI. Continuo arbitretur uxor tuo gnato), with which he gets his full support (270: AP. Fieri oportet). When the slave presents the details of his intrigue, we can see he is building his own self-confidence. In the beginning, Epidicus' pieces of advice are expressed using the rhetoric of occasio, the proper moment for action (270271: Em, nunc occasiost faciundi...), or deontic modality (274: Sic faciundum censeo...) - both indirect and less imposing (hence more polite) formulations of advisory discourse. Afterwards he passes on to more direct forms of persuasion suggesting that this logic of thinking is something obvious (276: PER. Quam ad rem istuc refert? EPI. Rogas?), as if he suddenly has become a wise man with all the right answers (286: PER. Sine me scire. EPI. Scibis, audi).

Epidicus' interactional pre-eminence in the entire advising scene is also shown by his tactics of building suspense. First, he suggests to his interlocutors that he has found a way to avoid any suspicions (285), then he waits for Periphanes to ask him questions about the details, and Apoecides to compliment him on his cunning (286), and finally he will reveal to them this best solution (287-8) and the details of putting it into practice (291-2). Such a complex convention of formulating advice serves not only the purposes of retardation and building suspense in the dialogue. It can be posited that it can also be a means of enacting a politeness strategy, since this discursive 'question-answer' model postpones the act of giving the actual strong recommendation, thus reducing the related threat to the interlocutors' autonomy. This phenomenon can be seen as a confirmation of P. Bourdieu's theory on the strict relationship between the time and the logic of social practices. In reference to his thought, P. J. Burton describes friendships in 
Plautus' comedies as emergent phenomena consolidating through the exchange of (material and non-material) goods in time. ${ }^{36}$ This makes one think immediately of an analogy with linguistic politeness, in which both the reciprocity of acts and the pace of implementation of particular moves are essential. The retardation of some conversational behaviours as a way of introducing some preparatory acts can constitute a useful politeness strategy. ${ }^{37}$

Returning to our cunning slave, Epidicus' communicative competence and insight in assessing the situation does not end here. Based on the dialogue between the old men he overheard at the beginning of the scene, he knows perfectly well that in the first setting Apoecides has aspired to the (interactional) role of adviser. When the slave usurps this function in the further interaction, he tries to compensate for this move with but a partial restoration of the interlocutor's 'face'. ${ }^{38}$ Although Epidicus is now setting the tone of the whole conversation, after a series of ever growing authoritative recommendations, he exerts himself to make acts of respect towards Apoecides (280: EPI. Quid tua autem, Apoecides?) as if his opinion still mattered in the new balance of power. Full consent and approval of the slave's plan in the old man's reply (281: AP. Quid ego iam nisi te commentum nimis astute intellego?) is just a confirmation of the peaceful coup d'etat achieved by the servus callidus. Epidicus' building authority gets to its culmination when he responds to Apoecides' positive facewants (291-2: hic erit optumus, / hic poterit cavere recte, iura qui et leges tenet), compensating, as it were, for his degradation to the role of a person accepting advice from a humble servant (the new adviser).

The new order, in which the slave manipulating the persuasion strategies dictates the mode of conduct to the two respected senes is sealed by the exchange where Periphanes urges his companion to thank the slave (!) for flattering him (293: PER. Epidico habeas gratiam). The scene ends with the full success of Epidicus, who has managed to put into practice his intrigue of

${ }^{36}$ Burton 2004, 210-11 (with further references to the sociological works by P. Bourdieu).

${ }^{37} \mathrm{Cf}$. the Donatus' comment on the senile linguistic behaviour in Terence (ad Ter. Eun. 338 41: hic ostenditur odiosa tarditas senis apud festinantem Chaeream) - discussed by Maltby (1979, $141-2)$.

${ }^{38}$ Goffman 1955, 219, provides several possible methods of overcoming critical interaction moments, when one of the participants suddenly falls out of their assumed role: "When the participants in an undertaking or encounter fail to prevent the occurrence of an event that is expressively incompatible with the judgments of social worth that are being maintained, and when the event is of the kind that is difficult to overlook, then the participants are likely to give it accredited status as an incident [...] At this point one or more participants find themselves in an established state of ritual disequilibrium or disgrace, and an attempt must be made to re-establish a satisfactory ritual state for them." In the debated scene from Epid. (255-93) by assuming the position of adviser, the slave makes Apoecides fall from his role determined at the beginning of the interaction. Accordingly, the following politeness strategies employed by Epidicus will function as corrective strategies to strengthen the old man in the new position of the person being advised. 
how to get out of a difficult situation without prejudice to family honour under the pretext of advising the pair of old men. Paradoxically, he has achieved all this using a couple of linguistic politeness 'tricks' by cleverly taking advantage of his interlocutors' concern for their own 'faces' as venerable and respected Roman citizens.

\section{CONCLUSION}

The high social status of the Roman (male) elite members based on their citizenship, education, financial dominance, and political role, translates - mutatis mutandis - into a characterisation of the figure of the senex on the stage of the palliata. E. Segal rightly emphasises that it is not the loss of material assets but the damage to his dignitas - understood both as his personal value and his public image - that seems to be the main concern of the cheated father (cf. Bacch. 1102-3, Capt. 781-7, Most. 1146-7). ${ }^{39}$ Our aim here has been to demonstrate how the social axiom of the old man's dignitas is being transferred in every verbal interaction into his 'face', a hic et nunc interpersonally constructed concept. By analysing various conversational situations leading to different linguistic politeness phenomena, we have tried to describe methods of negotiating this dynamic interactional image between the senex and his interlocutors.

The examples of dialogue openings suggest that the greeting scenes with old men in Plautus' comedies tend to have longer and more complex sequences. Such social ritual should be characterised not only by the completeness of particular moves (direct address forms, greeting formulae, 'small talk' sequences), but also their reciprocity. To lower-status interlocutors, with no danger to his 'face', the senex can omit some of the customary parts (e.g. towards slaves), or respond only perfunctorily (e.g. towards young men). In addition, it turns out that in some face-threatening acts (e.g. the speaker's shy confessions or criticising the addressee) special emphasis on the greeting ritual, followed by the friendly 'small talk' routine, already operates per se as positive politeness strategy, creating the sense of solidarity and arousing the partner's empathy right before positioning the main topic of the conversation (see Table 1). The same affiliative function is fulfilled by using elaborate greeting formulae and stressing the well-timedness of the encounter (eugae!). On the other hand, when senes either signal viva voce

\footnotetext{
${ }^{39}$ Segal 1987, 117-119. Emphasis put on high social status and political influences of the father has, obviously, its stage function. The wiser and more respected the victim of a subterfuge is, the greater is the comic effect and admiration for the witty schemer. The scholar (p. 119) points out: "It is, of course, surefire comic material when an older and wiser paterfamilias is overthrown by the lowliest member of his familia, especially for the Romans, who, under ordinary circumstances, were renowned for their reverential attitude toward older persons."
} 
or postpone the transition point to the first (relevant) topic, they try to respect the addressee's negative face-wants.

A more detailed analysis was required for the longer advising sequences, in which the characters (voluntarily or not) were part of an asymmetrical power system: one of them assumed a dominant role of the adviser, and the other/s

Table 1. Politeness strategies in dialogue opening (senex-senex)

\begin{tabular}{|c|c|c|}
\hline \multicolumn{2}{|r|}{ Positive (Affiliative) Politeness } & Negative (Redressive) Politeness \\
\hline \multirow{4}{*}{ 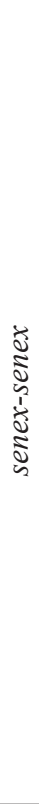 } & $\begin{array}{l}\text { Expression of joy } \\
\text { eugae! (Merc. 283) } \\
\text { o amice! (Trin. } 48)\end{array}$ & $\begin{array}{l}\text { Postponing ad rem transition } \\
\text { dicam, si videam tibi esse operam aut otium } \\
(\text { Merc. } 285)\end{array}$ \\
\hline & $\begin{array}{l}\text { Nominal (amicable) identification } \\
\text { amice }[\ldots] \text { atque aequalis }[\ldots] \text { Megaronides } \\
\text { (Trin. } 48-49)\end{array}$ & $\begin{array}{l}\text { Preparatory act to ad rem transition } \\
\text { da mi operam parumper paucis, Euclio, est } \\
\text { quod te volo / de communi re appellare mea } \\
\text { et tua. (Aul. } 199-200) \\
\text { sed hoc animum advorte }[. . .] \text { / nam ego } \\
\text { dedita opera huc ad te [ad]venio (Trin. } \\
66-67)\end{array}$ \\
\hline & \begin{tabular}{|l|} 
Elaborate greeting formulae \\
salvos atque fortunatus, Euclio, semper sies \\
(Aul. 182) \\
di te ament (Aul. 183, Most. 1130$)$ \\
iubeo te salvere (Most. 1128)
\end{tabular} & $\begin{array}{l}\text { Minimizing the duration of the dialogue } \\
\text { da mi operam parumper; paucis [...] est } \\
\text { quod te volo (Aul. 199) }\end{array}$ \\
\hline & $\begin{array}{l}\text { 'Small talk' routine } \\
\text { quid agis? quid fit? (Merc. 284) } \\
\text { ut vales? (Trin. 49) } \\
\text { valen? Valuistin (Trin. 50) } \\
\text { quid tu? recten atque ut vis vales? (Aul. 183) }\end{array}$ & \\
\hline
\end{tabular}

had to settle for a more receptive position of the advisee (see Table 2). This type of interaction also favoured any politeness strategies that were based mainly on indicating the distance between the interlocutors, and their full autonomy in accepting or rejecting consecutive suggestions of the partner. Extremely effective in this respect proved to be general gnomic expressions, stress put on the subjectivity of an opinion, and emphasizing the performative aspects of 'advising', that is to say, not 'giving orders' but only 'offering (subjectively) the best way to act'.

In the advising scenes between two befriended old men, evoking their mutual close relationships or including (rhetorically) the advisee in the problem solving process can also be interpreted as attempts to compensate for the attack on the recipient's independence in deciding.

Of particular interest are changes in the interactants' roles, and strategies for gradually gaining a dominant position in the dialogue. Naturally, in these 
Table 2. Politeness strategies in advice giving (senex-senex)

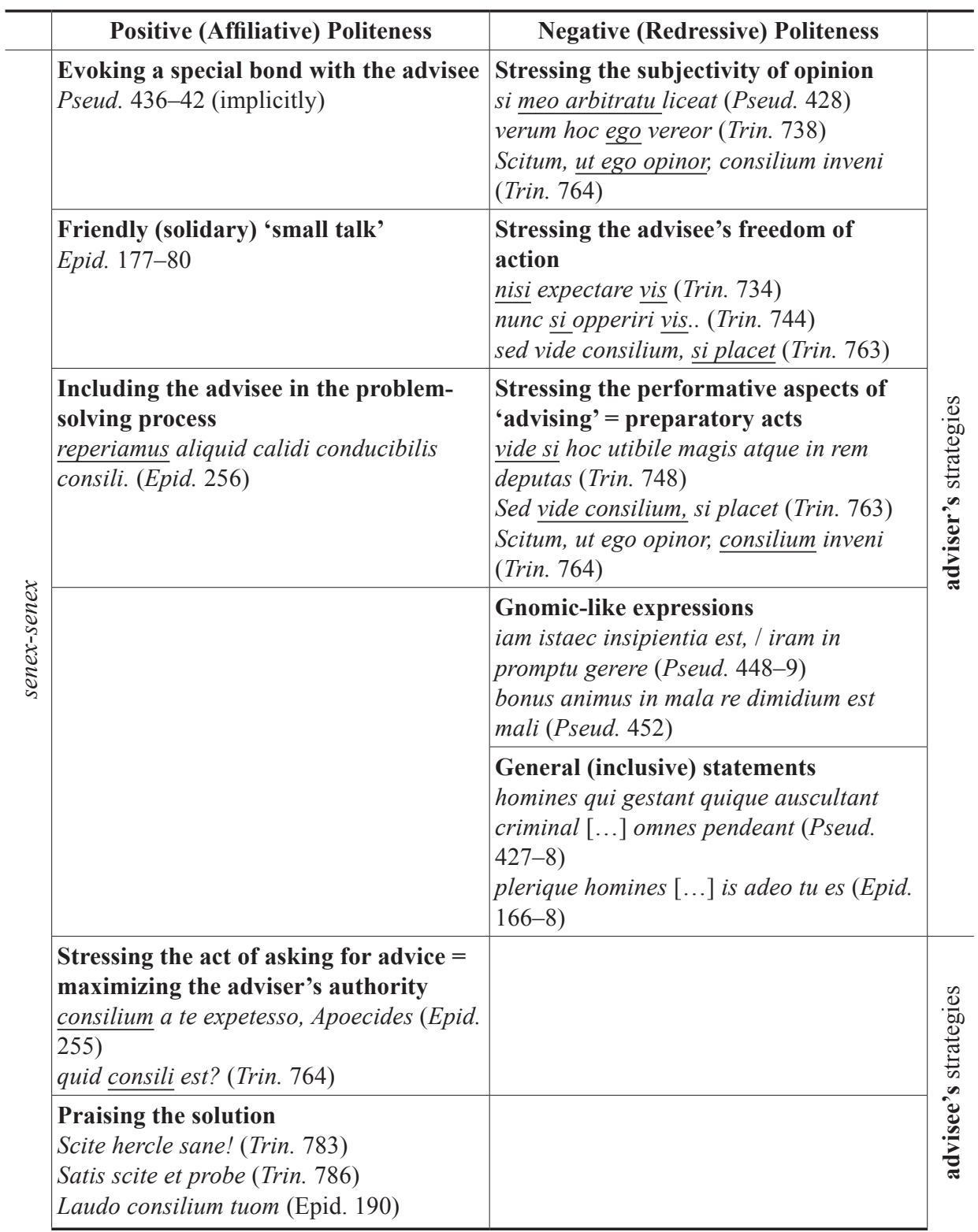

conversational manoeuvres servi callidi, masters of persuasion and strategical use of politeness are what excel. The clever slave seems to be least constrained by courtesy conventions, although the slave can use them efficiently to achieve their own objectives by aptly combining affirmation of the (higher status) addressee with redressive action. The cunning slave, for instance, would minimize his 
authority as an adviser (e.g. Epid. 261-2: vos [scil. senes] priores esse oportet, nos posterius dicere, / qui plus sapitis) in order to cynically take over the control in the whole interaction. It must be remembered, thus, that some aspects of the communicative realism among Plautus' characters were sacrificed for the sake of farce or depiction of a carnival upside-down world. ${ }^{40}$

In conclusion, we can distinguish two main tendencies in the literary approach to the linguistic politeness phenomenon related to the Plautine old men. The senex is characterised by an exceptional sensibility to the communicative bon ton, which is rarely underlain by any secondary conversational objectives. ${ }^{41}$ During every on-stage dialogue, by his knowledge of verbal interaction conventions, the old man highlights the education he received, and his ideological and linguistic conservatism manifesting itself in his adhesion to harmony in social life, where everyone knows where they belong. Even such a short selection of examples may already suggest that the comic senes will expect mostly negative politeness strategies from the other party. In this way their interlocutors (both high and low characters) are not only expressing due respect, but also they are giving the old men the illusion that they have a decisive role in particular exchanges of words, and the entire intrigue. In this sense, the politeness phenomenon, I argue, is tantamount for the final humiliation of the old men. From a wider perspective, the 'face' of the senex, (re)constructed in a series of interactions is being threatened and finally destroyed by the scheming slave. The greater the interpersonal distance between the old men and the servant, signalized throughout the play by linguistic politeness, the more spectacular seems to be the final triumph of the low character.

\section{BIBLIOGRAPHY}

Primary sources

Plautus. Comedies. vol. I-V. Ed., transl. by W. De Melo. 2011-2013. Cambridge.

${ }^{40} \mathrm{R}$. Ferri $(2009,21)$, comes to the same conclusion, when he recognises the limited realism of interaction as an element typical of Plautus: "Plautus does not represent what must have been standard politeness formulas for the sake of representing conversation or small talk, unlike Terence, but for comic effect.” Thus, the scholar seems to exclude any deeper psychological motivation underlying the conversational ritual in Plautus (e.g. in Most. 998-1009). In this paper I have attempted to prove that, even if the politeness related phenomena in Plautine comedies are often designed to achieve a "comic effect", they still represent a naturalistic and psychologically convincing element of the on-stage verbal interactions.

${ }^{41} \mathrm{~A}$ similar feature of the verbal behaviour of old men in Terence can be attested by a comment from Donatus: haec scaena plena est sententiarum senilium ad officia demonstranda (ad Ter. Ad. 592). 
Secondary sources

Berger 2013: Berger, Ł. 2013. "Doing things with words in Plautus' Pseudolus", Eos 100.2: 269-85. Berger 2015: Berger, Ł. 2015. "(Meta)discoursive Uses of Latin HEUS", Studia Romanica Posnaniensia 42.5: 8-11.

Brown, Levinson 1987: Brown, P., Levinson, S. C. 1987. Politeness: Some universals in language usage, Cambridge 1987.

Burton 2004: Burton, P.J. 2004. "Amicitia in Plautus: A Study of Roman Friendship Processes." American Journal of Philology 125.2: 209-243.

Ferri 2009: Ferri, R. 2009. "Politeness in Latin Comedy: Some Preliminary Thoughts." Materiali e discussioni per l'analisi dei testi classici. Pisa : Istituti Editoriali e Poligrafici Internazionali. 61: $15-28$

Goffman 1955: Goffman, E. 1955. "On Face-Work. An Analysis of Ritual Elements in Social Interaction", Psychiatry 18.3: 213-231.

Hall, J. 2009. Hall, J. 2009. Politeness and Politics in Cicero's Letters, Oxford.

Laver 1981: Laver, J. 1981. "Linguistic routines and politeness in greeting and parting." In Conversational routine, Ed. by F. Coulmas, 289-304. The Hague.

Maltby 1979: Maltby, R. 1979. "Linguistic characterization of old men in Terence." Classical Philology 74.2: 136-147.

Pizziconi 2009: Pizziconi, B. 2009. Politeness, In J. L. Mey (ed.) Concise Encyclopaedia of Pragmatics, Amsterdam, 706-710.

Searle 1969: Searle, J.R. 1969. Speech acts: An essay in the philosophy of language, Cambridge.

Segal 1987: Segal, E. 1987. Roman Laughter. The Comedy of Plautus, Oxford: Oxford University Press.

Unceta Gómez 2012: Unceta Gómez, L. 2012. "Cuando los sentimientos irrumpen: valores expresivos de las interjecciones primarias en las comedias de Plauto", In Estudios sobre teatro romano: el mundo de los sentimientos y su expression, Ed. by R. López Gregoris, 376-378. Zaragoza.

Unceta Gómez 2010: Unceta Gómez, L. 2010. "La expresión de agradecimiento en la comedia latina." In Latin Linguistics Today: Akten des 15. Internationalen Kolloquiums zur Lateinischen Linguistik (Innsbruck, 4-9 April 2009) Ed. by P. Anreiter, M., Kienpointner. 625-637. Innsbruck.

Watts, R.J. 2003: Watts, R.J. 2003. Politeness, Cambridge.

\section{EL SENEX Y LA CORTESÍA LINGÜÍSTICA EN LAS COMEDIAS DE PLAUTO}

\section{Resumen}

Según se desprende de la lectura de las obras plautinas, la caracterización de la figura del senex se centra en destacar su dignidad personal y pública como paterfamilias, un miembro de la élite económica y política. En este artículo se identifica la dignitas de los ancianos -que se revela en cada interacción verbal- con el concepto de imagen social empleado por la teoría la cortesía lingüística.

A continuación, se analizan dos tipos de comportamiento lingüístico (la apertura dialógica y las secuencias de aconsejar), donde el senex interactúa con personajes de diferente estatus social. En cuanto a las escenas de apertura dialógica (salutationes) realizadas por y hacia los ancianos, se percibe un alto grado de ritualización, tanto más evidente entre senes. Las secuencias en las que un noble paterfamilias recibe consejos necesitan también de varias estrategias de cortesía lingüística 
para que su imagen social no se vea comprometida, puesto que este tipo de interacción verbal conlleva una asimetría de poder entre los hablantes.

En una breve revisión de dichas escenas, se señalan los recursos utilizados tanto para afirmar la imagen positiva del interlocutor (cortesía positiva), como para expresar respeto y reverencia hacia él (cortesía negativa). En consecuencia, la cortesía lingüística, como fenómeno conversacional, resulta un importante recurso para la caracterización de los personajes plautinos, no a nivel léxico sino pragmático. 